\title{
THE STATUS OF Oryctes rhinoceros Nudivirus (OrNV) INFECTION IN Oryctes rhinoceros (Coleoptera: Scarabaeidae) IN INDONESIA
}

\author{
SAT RAHAYUWATI*; YAYI MUNARA KUSUMAH*; SUDHARTO PRAWIROSUKARTO**; DADANG* \\ and TEGUH SANTOSO*
}

\begin{abstract}
Oryctes rhinoceros is a major problem on oil palm in Indonesia, especially during replanting. Oryctes rhinoceros Nudivirus (OrNV) is a virus that infects both larvae and adults of $\mathrm{O}$. rhinoceros. An extensive survey of OrNV infection on O. rhinoceros in Indonesia has not been conducted. The objective of the research is to identify the rate of OrNV infection in its host from various sampling sites in Indonesia. Adults and larvae of O. rhinoceros were collected from Sumatra, Belitung, Java, Kalimantan and Sulawesi. Infected larvae were determined by their physical character, i.e. prolapsed rectum, while infected adults were determined by dissection to observe the swollen midguts. The incidence of OrNV infection in larvae was difficult to estimate, as only 11 out of 417 larvae showed prominent symptoms. OrNV infection rates in adults O. rhinoceros in oil palm plantations in Sumatra, Belitung and Kalimantan were between $64 \%$ and $90 \%$, and female O. rhinoceros could still produce eggs even when they were infected by OrNV. In Sulawesi and Java, which are not major oil palm plantation centres, OrNV infection rates were below 16\%. It is suspected that most of the $\mathrm{O}$. rhinoceros population from areas intensively cultivated with oil palm is persistently or latently infected by OrNV and the beetles remain fertile.
\end{abstract}

Keywords: biological control agents, infection rates, Nudivirus, survey.

Received: 10 July 2019; Accepted: 30 January 2020; Published online: 28 July 2020.

\section{INTRODUCTION}

The current status of Oryctes rhinoceros in Indonesia is that it is the main pest in coconut and oil palm plantations (Susanto et al., 2012) and harmful outbreaks of $O$. rhinoceros frequently developed in replanted areas (Zelazny et al., 1992; Chenon

\footnotetext{
* Plant Protection Department,

Faculty of Agriculture, Bogor Agricultural University,

Jalan Kamper No. 1, Kampus IPB Dramaga,

16680 Bogor, Java, Indonesia.

E-mail: sat_rahayuwati@yahoo.com

** Crop Protection,

PT. Astra Agro Lestari Tbk,

Kota Jakarta Timur,

13920 Jakarta, Indonesia.
}

and Pasaribu, 2005; Salim and Hosang, 2013). Decomposed coconut and oil palm trunks provide extensive $O$. rhinoceros breeding sites, and zero burning regulations have been contributing to rising O. rhinoceros populations (Purba and Sudharto, 2000; Abidin et al., 2014). Extremely large numbers of $O$. rhinoceros have been found in oil palm plantations, with a $2 \times 2 \times 0.2 \mathrm{~m}^{3}$ sample of decomposed empty fruit bunches containing 4441 larvae, 12 pupae and 201 adults having been reported (Purba et al., 1999). Larval populations in natural coconut breeding sites were smaller than in oil palms, at only $3-48$ individual for $1 \times 1 \times 0.5 \mathrm{~m}^{3}$ (Indriyanti et al., 2017).

The discovery of the pheromone active ingredient, ethyl 4-methyl octanoate, as an attractant for $\mathrm{O}$. rhinoceros adults revolutionised 
environmental pest control (Renou et al., 1998; Chenon et al., 2001). Chenon and Pasaribu (2005) reported that thousands of adults had been trapped with pail pherotraps in North Sumatra. Combination of several control methods for $O$. rhinoceros have been suggested, such as manual pick-up of larvae from decomposed palm trunks, bio-traps made from decomposed empty fruit bunches, Metarhizium anisopliae application in breeding sites, camphor treatment in young shoots, manual pick-up of adults from their tunnels, and pheromone traps (Purba et al., 1999; Susanto et al., 2012). Although various control methods have been used, $O$. rhinoceros remains a substantial problem. Pheromones have been found to be effective but expensive, and only large private oil palm companies are capable of using pheromones for control so far. The cost factor has prevented the use of commercial pheromone products by small farmers.

OrNV is non-occluded Baculovirus belong to family Nudiviridae, genus Alphanudivirus (Jehle et al., 2013). OrNV infects larval and adult stages of $O$. rhinoceros in midgut epithelial cells and the fat body (Huger, 2005; Jehle et al., 2013). Bedford (2014) states that OrNV has been used as a main control of O. rhinoceros in non-endemic areas such as the Pacific; unfortunately, however, in areas such as Indonesia and Malaysia, OrNV has not been a main method of control. Hopes for effective OrNV utilisation lie in the differences of pathogenicity between isolates. There are some slight enzymatic restrictions of EcoRI and HindII patterns in Indonesian isolates (Kobayashi and Somowiyarjo, 1995). The most virulent OrNV isolate, isolate $\mathrm{B}$, has delivered significant results for O. rhinoceros control in Malaysia (Ramle et al., 2005). Benefits of OrNV as an O. rhinoceros biological control are that it is environmental-friendly, cheap and permanent.

Survey of OrNV incidence across a wide area in Indonesia have not been conducted. Indonesia is a place of origin of OrNV (Huger, 1966; Bedford, 2014) and it is thought to be found as various isolates with different levels of pathogenicity. This article presents preliminary results of the status of OrNV infection rate in O. rhinoceros taken from the survey. Preserved $O$. rhinoceros raw organ containing OrNV will be used for pathogenicity tests.

\section{MATERIALS AND METHODS}

\section{Sampling Locations}

Third instar larvae and adults of O. rhinoceros were collected from Simalungun, North Sumatra; Rokan Hulu, Riau; Sijuk, Belitung; Sukabumi, West Java; Tayu, Central Java; East Kotawaringin, Central Kalimantan; Penajam Paser, East Kalimantan; Mamuju Utara, West Sulawesi; and Morowali, Central Sulawesi (Table 1).

TABLE 1. LOCATION, THE NUMBER OF Oryctes rhinoceros (Coleoptera: Scarabaeidae) AND GLOBAL POSITIONING SYSTEM (GPS) COORDINATES OF SAMPLING SITES

\begin{tabular}{|c|c|c|c|c|}
\hline \multirow{2}{*}{ No. } & \multirow{2}{*}{ Location } & \multirow{2}{*}{ GPS coordinates } & \multicolumn{2}{|c|}{ O. rhinoceros } \\
\hline & & & Adults & Larvae \\
\hline 1 & $\begin{array}{l}\text { Marihat Baris, Siantar sub-district, Simalungun Regency, } \\
\text { North Sumatera }\end{array}$ & $2.9223,99.0894$ & 57 & 50 \\
\hline 2 & Kalianta Estate, Rokan Hulu Regency, Riau & $0.465870,100.820694$ & 61 & 50 \\
\hline 3 & Sijuk Village, Belitung Island & $-2.55847,107.74773$ & 50 & 50 \\
\hline 4 & Parungkuda sub-district, Sukabumi Regency, West Java & $-6.844,106.7526$ & 50 & 50 \\
\hline 5 & $\begin{array}{l}\text { Bulumanis Lor, Margoyoso sub-district, Pati Regency, } \\
\text { Central Java }\end{array}$ & $-6.608368,111.068438$ & 60 & 50 \\
\hline $6 a$ & $\begin{array}{l}\text { Rubung Buyung, Cempaga, East Kotawaringin Regency, } \\
\text { Central Kalimantan }\end{array}$ & $-2.19719,113.06786$ & 74 & - \\
\hline $6 \mathrm{~b}$ & $\begin{array}{l}\text { Pundu, Cempaga Hulu, East Kotawaringin Regency, Central } \\
\text { Kalimantan }\end{array}$ & $-1.97657,113.10685$ & - & 50 \\
\hline 7 & $\begin{array}{l}\text { Babulu Darat, Babulu sub-district, Penajam Paser Utara } \\
\text { Regency, East Kalimantan }\end{array}$ & $-1.495287,116.406840$ & - & 50 \\
\hline $8 \mathrm{a}$ & $\begin{array}{l}\text { Kumasari, Sarudu sub-district, Mamuju Utara Regency, West } \\
\text { Sulawesi }\end{array}$ & $-1.701959,119.367979$ & 54 & - \\
\hline $8 b$ & $\begin{array}{l}\text { Tammarunang, Duripoku sub-district, Mamuju Utara } \\
\text { Regency, West Sulawesi }\end{array}$ & $-1.648731,119.411832$ & - & 50 \\
\hline \multirow[t]{2}{*}{9} & $\begin{array}{l}\text { Beteleme village, Lembo sub-district, Morowali Regency, } \\
\text { Central Sulawesi }\end{array}$ & $-2.1396,121.2839$ & 3 & 17 \\
\hline & & & 409 & 417 \\
\hline
\end{tabular}




\section{Collection of $O$. rhinoceros Adults and Larvae}

Adults were trapped by pail pherotraps equipped with vanes. Larvae were collected from decomposed coconut and oil palm trunks, decomposed sawdust and other organic materials. Collected samples were sent to the Insect Pathology Laboratory, Plant Protection Department, Bogor Agricultural University between January and April 2018.

\section{Observation of OrNV Infection in Larvae and Adults by Physical Characters}

Larvae were identified using a simplified field key for O. rhinoceros (Beaudoin-Ollivier et al., 2000). Infected larvae were identified by swollen, transparent abdomens. Sometimes the abdomen has a white, shiny, pearlescent appearance (Huger, 1966). Heavily infected larvae also show signs of prolapsed rectum (Huger, 2005). Larvae were observed for the OrNV infection by external characters as described by Huger (1966; 2005) and also on their digestive tracts. The digestive tract was cleaned with sterilised aquadest and the midgut sections were observed.
Adults were measured from horn to abdominal tip. Fresh adults were opened along the line between the dorsal and ventral abdomen. Infected adults were characterised by a whitish swollen gut (Crawford and Zelazny, 1990; Burand, 1998; Huger, 2005) and their eggs were counted.

\section{RESULTS AND DISCUSSION}

\section{OrNV Infection Rate in Larvae and Adults}

Fifty larvae were obtained from each of the nine sampling points except for Morowali, Central Sulawesi, from which only 17 were collected (Table 1). Prolapsed rectum was found in only three larvae from Riau, while only four larvae with white swollen abdomens were found in each of the Riau and Belitung sites (Figures 1 and 2). Larvae with a prolapsed rectum had more hemolymph liquid but there were no differences between their guts and those of the healthy larvae. Infected larvae can only be identified by their external body symptoms. There were 406 larvae that had no external symptoms, and a molecular method might be more accurate for OrNV detection than by relying on physical observation.

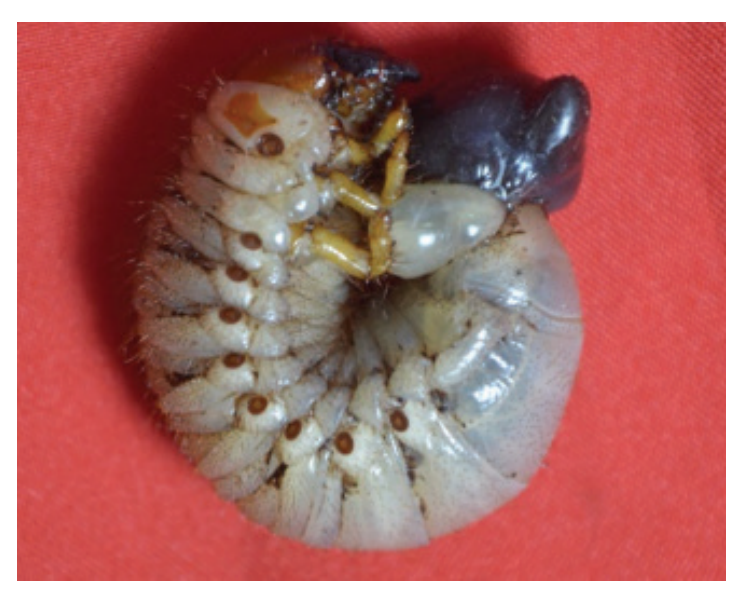

Figure 1. Motionless third instar larva of O. rhinoceros with prolapsed rectum as a strong symptom of Nudivirus (OrNV) (Huger, 1966).

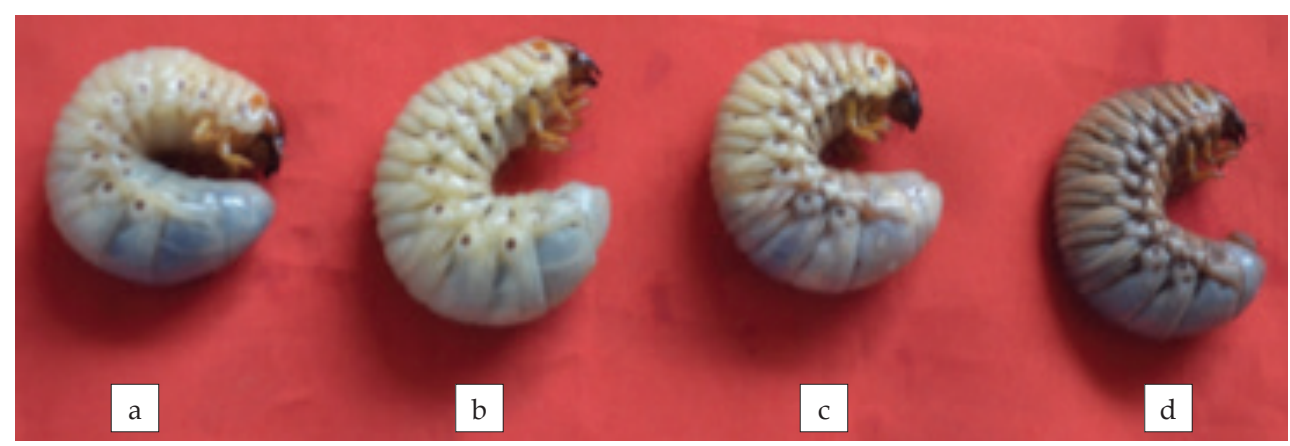

Figure 2. Development of Nudivirus (OrNV) infections from mild to severe. Larvae (a) was still alive; larvae (b) and (c) were alive but motionless; and larvae (d) was dead with a prolapsed rectum. 
From eight sampling sites, 409 adults were collected: 251 females and 158 males (Table 1). There were 207 adults with white swollen midguts (Figure 6); the rest had transparent, beige, brownish, or black midguts (Table 2; Figures 3, 4 and 5). Those adults with white midguts had gut diameters ranging from 2 to $4 \mathrm{~mm}$. Those with a larger midgut diameter contained a large amount of white liquid and were fragile. Adults with brown, beige, and transparent midguts were assumed to be healthy (Crawford and Zelazny, 1990). Those with black midguts appeared to be ailing and were moving less than healthy specimens.

TABLE 2. NUDIVIRUS (OrNV) INFECTION STATUS IN O. rhinoceros ADULTS BASED ON COLOUR OF THE MIDGUT

\begin{tabular}{lccr}
\hline Midgut colour & $\begin{array}{c}\text { Status: } \\
\text { healthy }\end{array}$ & $\begin{array}{c}\text { Status: } \\
\text { infected }\end{array}$ & Total \\
\hline Brown & 158 & - & 158 \\
Beige & 24 & - & 24 \\
Black & 9 & - & 9 \\
Transparent & 11 & - & 11 \\
White & - & 207 & 207 \\
\hline Total & 202 & 207 & 409 \\
\hline
\end{tabular}

Population of adults from eight sampling sites had different degrees of OrNV infection. Adults

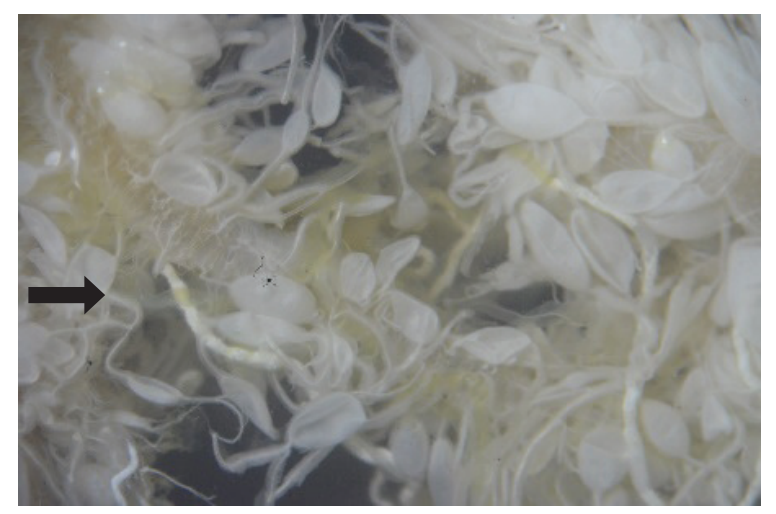

Figure 3. Transparent midgut of O. rhinoceros adult.

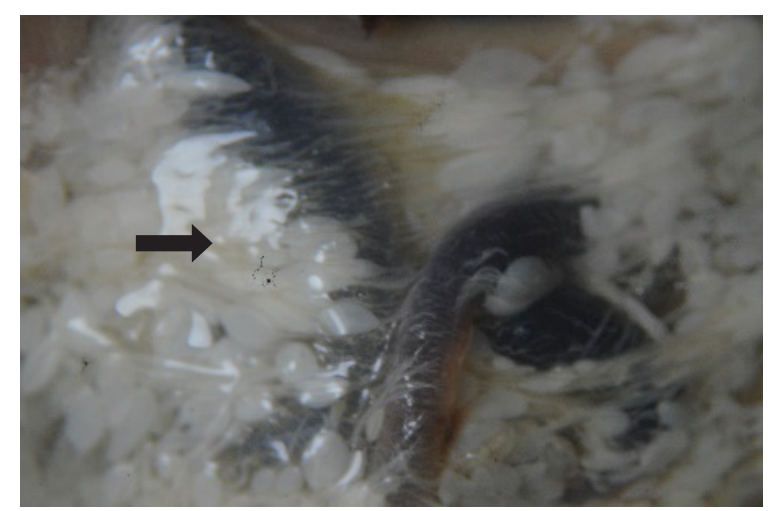

Figure 5. Adult of $\mathrm{O}$. rhinoceros with black midgut. This beetle appeared to be ailing and was moving less. from Riau and North Sumatra had high rates of OrNV infection, at $90.2 \%$ and $89.5 \%$, respectively, while adults from Java and Sulawesi had low OrNV infection rates of below $16 \%$. OrNV infection rates in Belitung and Central Kalimantan were also high at above $60 \%$ and $70 \%$ (Figure 7). It has been suggested that there is an interaction between intensity of oil palm plantation and the incidence of OrNV infection.

Oil palms have been cultivated since 1911 in North Sumatra, 1922 in South Sumatra, and 1981 in Kalimantan (Pamin, 1998; Suprianto et al., 2016). High OrNV incidence was found to be concomitant with intensive oil palm cultivation. In contrast, Java and Sulawesi are not intensively cultivated with oil palms and have low OrNV incidence. Areas under oil palm cultivation are 36163 ha in West Java and 354000 ha in Sulawesi (Directorate General of Estate Crop RI, 2016; Gapki, 2015). Bedford (2013) has reported low OrNV incidence of $7 \%-25 \%$ in the Philippines and medium-to-high OrNV incidence of $41 \%-75 \%$ in India. Oil palm is the most important commodity crop in Malaysia with total planted areas of over 4.9 million hectares (MPOB, 2011). OrNV incidence in Malaysia has been reported as high as 75\%-100\% (Ramle et al., 2005). High OrNV incidence in Malaysia is also concomitant with intensive oil palm cultivation.

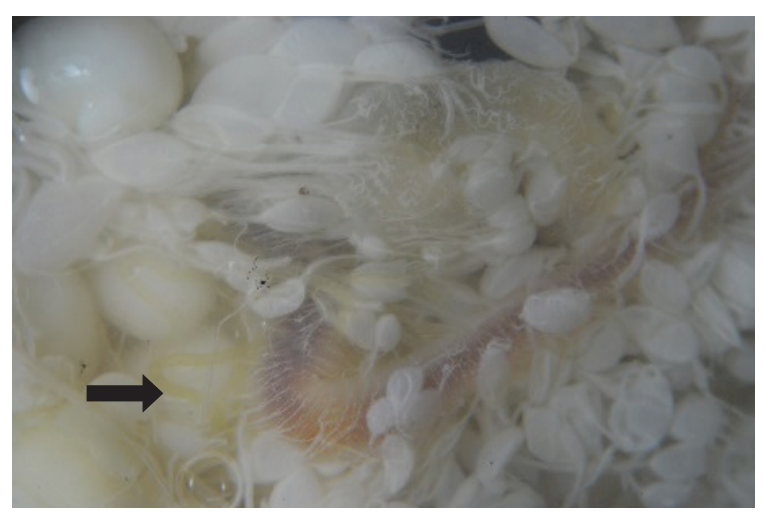

Figure 4. Brown midgut of O. rhinoceros adult.

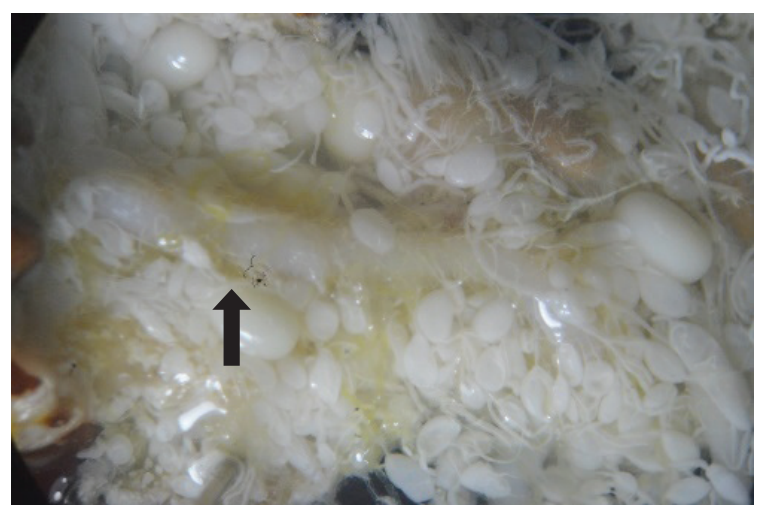

Figure 6. White, swollen midgut as a feature of obvious Nudivirus $(\mathrm{OrNV})$ infection in $\mathrm{O}$. rhinoceros. 


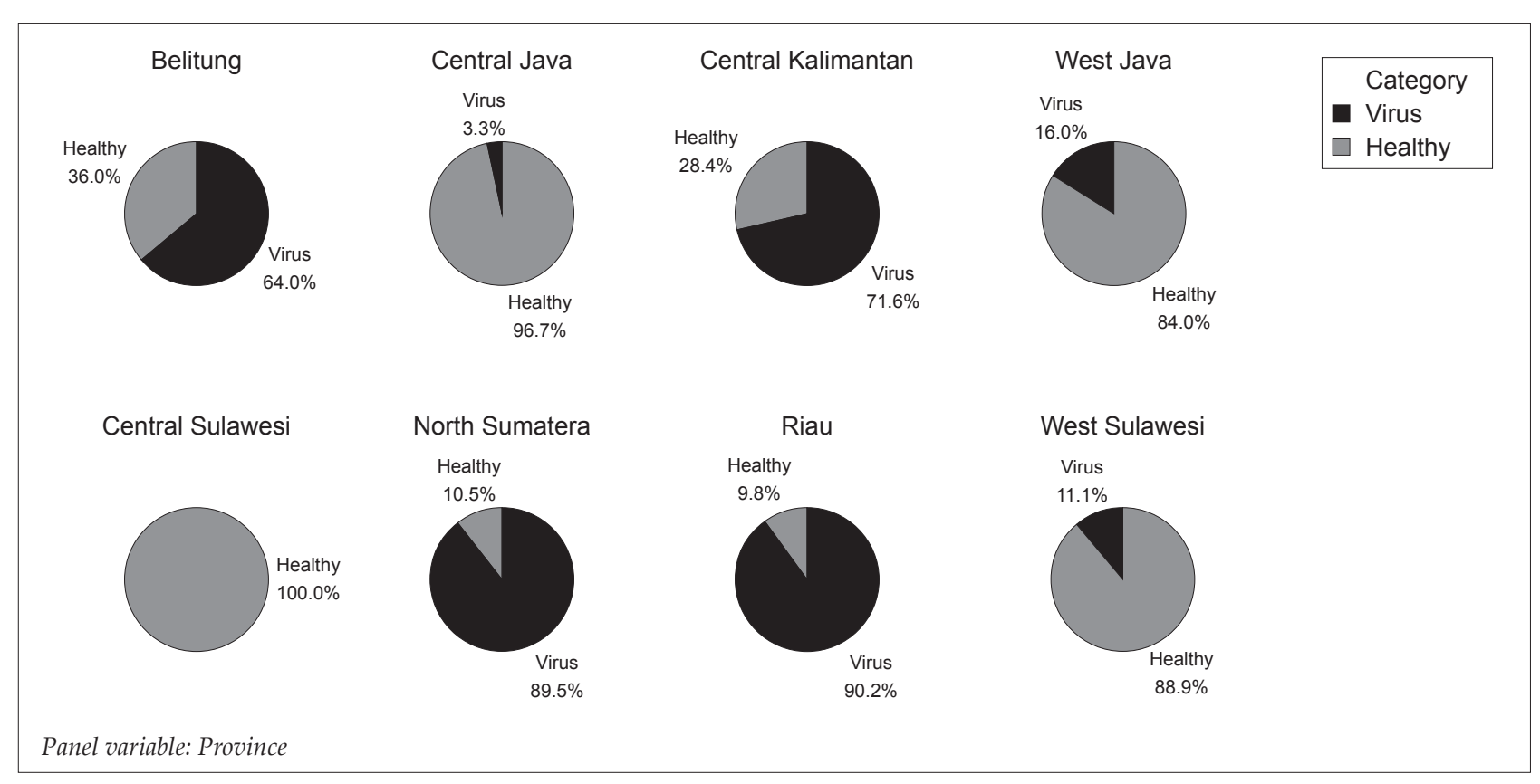

Figure 7. Nudivirus (OrNV) infection rates in adult Indonesian O. rhinoceros.

\section{Number of Eggs in Infected Females}

Healthy females $O$. rhinoceros and those infected by OrNV have almost the same number of eggs, 128 and 122. Of those females with OrNV infection, 57\% had eggs in their abdomens (Figure 8). Females $O$. rhinoceros from oil palm intensive cultivation areas, i.e. Sumatra, Belitung and Kalimantan still produced eggs even when they were infected by OrNV (Figure 9). While, infected females O. rhinoceros from Java and Sulawesi tended not to have eggs (Figure 10).

Although there were high OrNV incidence in Sumatra, Belitung and Kalimantan, O. rhinoceros still survived in good reproductive condition. Zelazny and Alfiler (1991) stated that OrNV was an important control of O. rhinoceros in South-east Asia, but $O$. rhinoceros outbreaks continue to occur even though some of the individuals in populations are infected. Evidence suggests that the extensive availability of organic material at replanting is the reason for $O$. rhinoceros outbreaks (Chenon and Pasaribu, 2005; Salim and Hosang, 2013). The OrNV may have had significant opportunities to change its genetics and circulate to other abundant hosts. Crawford and Zelazny (1990) stated that OrNV genomics always changed with nonlethal infections.

OrNV is a species in the genus Alphanudivirus, family Nudiviridae (Jehle et al., 2013). Nudivirus adopts with vertical and horizontal modes of infection (Williams et al., 2017). Vertical infection is also known as latent or persistent infection (Wang and Jehle, 2009) and changes the virus to become asymptomatic. Latent infections burst into active depending on host environmental resistance or host physiological stresses. Activated viruses from a symptomless condition cause lethal infections and eventually horizontal transmission occurs (Cory, 2015). It is suspected that most Indonesian O. rhinoceros populations from oil palm intensive cultivated areas are persistently or latently infected by OrNV and the beetles remain fertile.

\section{Adults Attracted by Pheromone and Size of the Adults}

Pheromones attracted more females than males, with the highest percentage of $77.2 \%$ in North Sumatra and data average from eight sampling sites was $61.5 \%$ (data not shown). Other research has also indicated that females are more strongly attracted by pheromones than males, with results of $68 \%$ in India, $60 \%$ in Malaysia and $81 \%$ in North Sumatra. These females may have been searching for mates or seeking breeding sites (Bedford, 2014; Zelazny and Alfiler, 1991; Morin et al., 1996). Attracted females may come from breeding sites or the crowns of oil palms. Emergent adults fly to the crowns of palms for five weeks then fly to lay eggs in breeding sites where they stay for seven weeks, before returning to drill into oil palm crowns to feed (Norman and Basri, 2004).

Both male and female $O$. rhinoceros had a median length of $4 \mathrm{~cm}$. First quartile (Q1) female length was $3.8 \mathrm{~cm}$, with $4.3 \mathrm{~cm}$ for third quartile (Q3). Q1 male length was $3.7 \mathrm{~cm}$, with $4.2 \mathrm{~cm}$ for Q3. Adult length is dependent on nutritional values during larval phases (Pallipparambil, 2015). The number of female $O$. rhinoceros that is attracted by pheromone and the adult size captured from field seem not to be affected by the presence of OrNV infection. 
Number of eggs inside $O$. rhinoceros adult

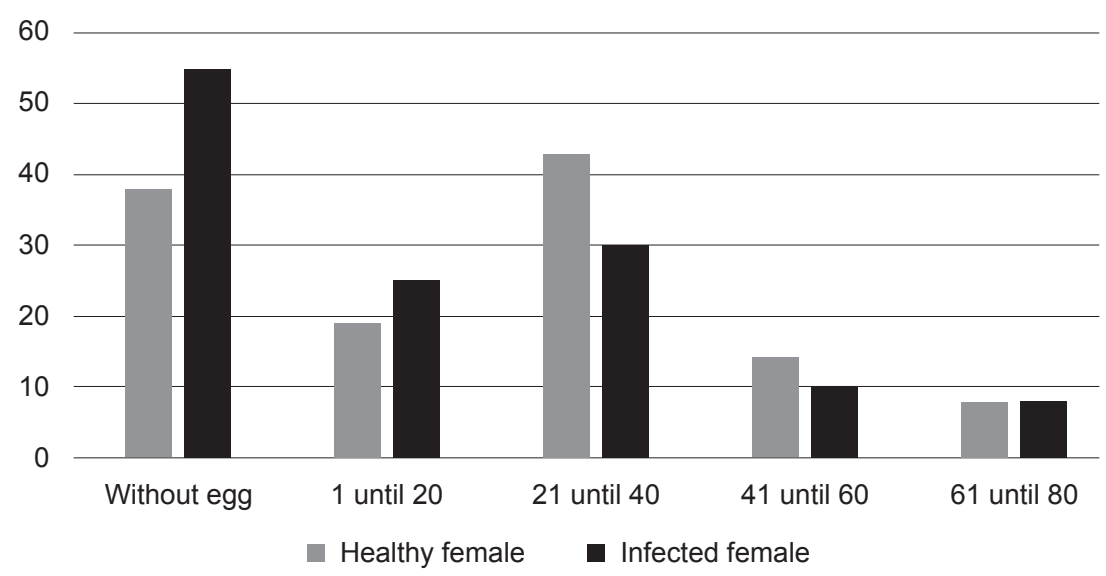

Figure 8. Number of eggs inside the O. rhinoceros adult.

Number of eggs inside O. rhinoceros adult

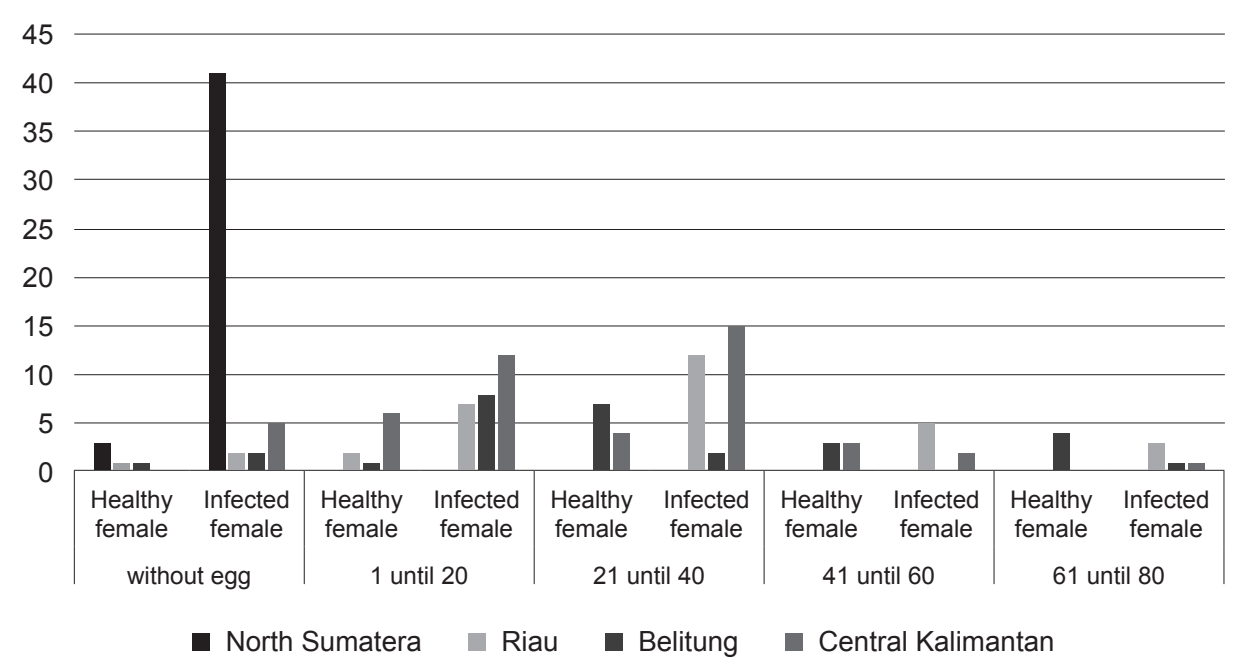

Figure 9. Female O. rhinoceros from Riau, Belitung and Central Kalimantan were produced eggs although infected by Nudivirus (OrNV).

Number of eggs inside O. rhinoceros adult

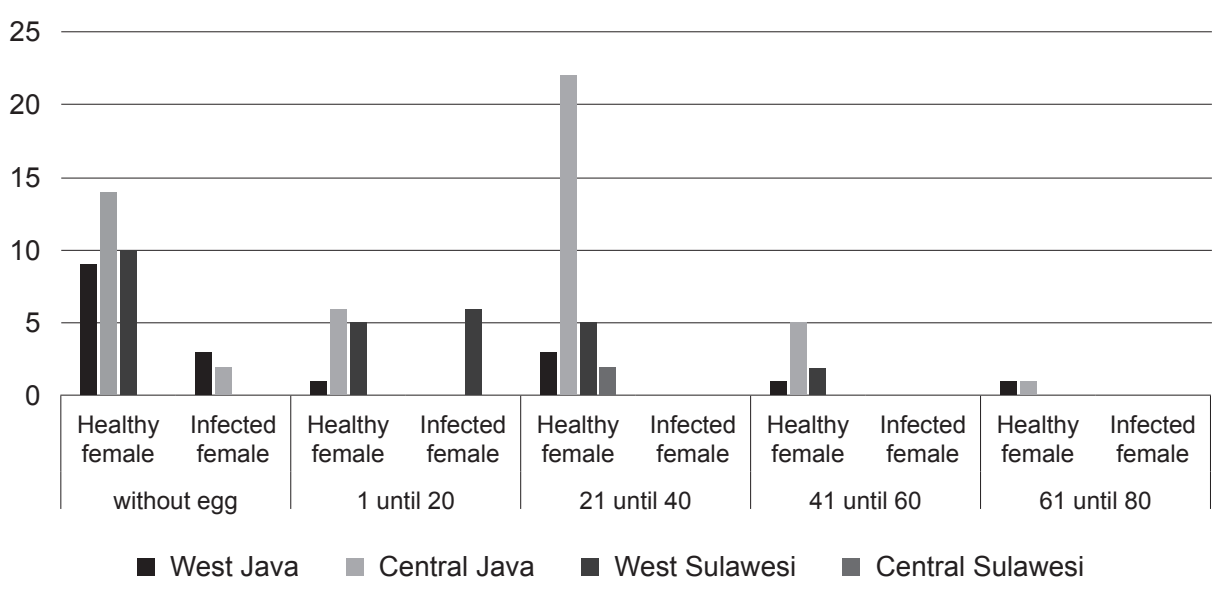

Figure 10. Infected female O. rhinoceros from West Java, Central Java, West Sulawesi and Central Sulawesi tended not to produce eggs. 


\section{CONCLUSION}

OrNV infected larvae can be identified by external body characteristics, while infected adults can be identified by internal identification of whitish, swollen midgut. High incidence of OrNV infection in $O$. rhinoceros can be correlated with intensive oil palm cultivation such as found in Sumatra, Belitung and Kalimantan. In some cases, infected adults from Sumatra, Belitung and Kalimantan were found to be alive and with eggs in their abdomens.

\section{ACKNOWLEDGEMENT}

The authors are grateful for the scholarship and research funding from Lembaga Pengelola Dana Pendidikan (LPDP)(Endowment Fund for Education), Ministry of Finance, Republic of Indonesia. We also would like to thank the following institutions for assistance in samples collection: Indonesian Oil Palm Research Institute (IOPRI), Indonesian Industrial Beverage Crops Research Institute (IIBCRI), PT Anugerah Sarana Hayati, PT Bumitama Gunajaya Agro, Agency for Forestry and Estate Crops in Pati District, Central Java.

\section{REFERENCES}

Abidin, C M R Z; Ahmad, A H; Salim, H and Hamid, N H (2014). Population dynamics of Oryctes rhinoceros in decomposing oil palm trunks in areas practicing zero burning and partial burning. J. Oil Palm Res. Vol. 26(2): 140-145.

Beaudoin-Ollivier, L; Prior, R N B and Laup, S (2000). Simplified field key to identify larvae of some rhinoceros beetles and associated scarabs (Coleoptera: Scarabaeoidea) in Papua New Guinea coconut developments. Annals of the Entomological Society of America, 93(1): 90-95.

Bedford, G O (2013). Biology and management of palm dynastid beetles: Recent advances. Annual Review of Entomology, 58: 353-372.

Bedford, G O (2014). Advances in the control of rhinoceros beetle, Oryctes rhinoceros in oil palm. J. Oil Palm Res. Vol. 26: 183-194.

Burand, J P (1998). Nudiviruses in the insect. Viruses. Plenum Press, New York. p. 69-90.

Chenon, D R; Asmady, $\mathrm{H}$ and Sudharto, P S (2001). New improvement of pheromone for the management of the rhinoceros beetle in oil palm plantations. Proc. of the 2001 PIPOC International Palm Oil Congress: Cutting Edge Technologies for
Sustained Competitiveness - Agriculture Conference. MPOB, Bangi. p. 624-632.

Chenon, R D and Pasaribu, H (2005). Oryctes rhinoceros Management at PT. Tolan Tiga (SIPEF Group) North Sumatra Indonesia. Oil Palm Technical Meetings. 13-14 September 2005. Yogyakarta, Indonesia. p. 102-113.

Cory, S (2015). Insect virus transmission: Different routers to persistence. Insect Science, 8: 130-135.

Crawford, A M and Zelazny, B (1990). Evolution in Oryctes baculovirus: Rate and types of genomic charge. Virology, 174(1): 294-298.

Directorate General of Estate Crops RI (2016). Oil palm in statistics of plantation crop from 20152017. Directorate General of Estate Crops, Jakarta, Republic of Indonesia.

Gapki (Indonesian Association of Oil Palm Entrepreneurs) (2015). Myth 7-04 oil palm plantation as deforestation trigger in Sulawesi. https: / / gapki.id / news / 5932 / mitos-7-05-kebunsawit-pemicu-utama-konversi-hutan-menjadi-nonhutan-sulawesi\#, accessed on 9 July 2019.

Huger, A M (1966). A virus disease of the Indian rhinoceros beetle, Oryctes rhinoceros (Linnaeus), caused by a new type of insect virus, Rhabdionvirus oryctes gen n sp.n. J. Invertebrate Pathology, 8: 38-51.

Huger, A M (2005). The Oryctes virus: Its detection, identification and implementation in biological control of the coconut palm rhinoceros beetle, Oryctes rhinoceros (Coleoptera: Scarabaeidae). J. Invertebrate Pathology, 89: 78-84.

Indriyanti, D R; Anggraeni, S D and Slamet (2017). Density and composition of Oryctes rhinoceros (Coleoptera: Scarabaeidae) stadia in field. ARPN J. Engineering and Applied Science, 12(22): 6364-6371.

Jehle, J A; Burand, J; Herniou, E; Elisabeth, H; Harrison, R; Arif, B; Thielmann, D; Van Ooers, $\mathrm{M}$ and Becnel, J (2013). Creation of a new family nudiviridae including two new genera and three species. International Committee on Taxonomy of Viruses (ICTV).

Kobayashi, J and Somowiyarjo, S (1995). Properties of Oryctes baculovirus isolated in Indonesia. J. Perlindungan Tanaman Indonesia, 1(1): 41-46.

Morin, J P; Rochat, D; Malosse, C; Lettere, M; De Chenon, R D; Wibwo, H and Descoins, C (1996). Ethyl 4-methyloctanoate major component of male pheromone in Oryctes rhinoceros (L.) (Coleoptera 
Dynastidae). Comptes Rendus de L'Academie des Sciences, Serie III, Sciences de la vie 319(7): 595-602. Abstract online access https://europepmc.org/ abstract/med/9011322, accessed on 9 July 2019.

MPOB (2011). Malaysian palm oil industry. http: / / palmoilworld.org/about-malaysian-industry.html, accessed on 10 December 2019.

Norman, K and Basri, M W (2004). Immigration and activity of Oryctes rhinoceros within a small oil palm replanting area. J. Oil Palm Res. Vol. 16: 64-77.

Pallipparambil, G R (2015). New Pest Response Guidelines for Oryctes rhinoceros (L) (Coleoptera: Scarabaeidae). United States Department of Agriculture (USDA).

Pamin, K (1998). A hundred and fifty years of oil palm development in Indonesia from the Bogor botanical garden to the industry. Proc. of the International Oil Palm Conference. Nusa Dua, Bali, Indonesia. 23-25 September 1998. p. 3-23.

Purba, R Y; Sudharto, P S and De Chenon, R D (1999). Utilization of oil palm fruit empty bunches as Oryctes rhinoceros (L.) traps in oil palm plantations. J. Penelitian Kelapa Sawit, 7(2): 105-114.

Purba, R Y and Sudharto, P S (2000). Utilization of Baculovirus oryctes as Oryctes rhinoceros L. control in oil palm plantations. Oil Palm Research Report Fiscal Year 1999-2000 DIP.119/XXiX/007/4/1999. Indonesian Oil Palm Research Institute, Medan.

Ramle, M; Wahid, M B; Norman, K; Glare, T R and Jackson, T A (2005). The incidence and use of Oryctes virus for control of rhinoceros beetle in oil palm plantation in Malaysia. J. Invertebrate Pathology, 89: 85-90.
Renou, M; Tauban, D and Morin, J P (1998). Structure and function of antennal pore plate sensilla of Oryctes rhinoceros (L.) (Coleoptera: Scarabaeidae). International J. Insect Morphology and Embryology, 27(3): 227-233.

Salim and Hosang, M L A (2013). Oryctes rhinoceros aggression in several coconut kopyor production centers and potential application of entomopathogenic Metarhizium anisopliae. Buletin Palma, 14(1): 47-53.

Suprianto, E; Arrasyid, M H and Siregar, H H (2016). Inspigraph: The Oil Palm in Colonial Era and Indonesian Post Independence. Indonesian Oil Palm Research Institute, Indonesia.

Susanto, A; Prasetyo, A R; Sudharto, PS; Priwiratama, $\mathrm{H}$ and Roziansha, T A (2012). The Management of Oryctes rhinoceros in Oil Palm Plantation. Indonesian Oil Palm Research Institute, Indonesia.

Wang, Y and Jehle, J A (2009). Nudiviruses and other large, double-stranded circular DNA viruses of invertebrates: New Insights on an Old Topic. J. Invertebrate Pathology, 101: 187-193.

Williams, T; Virto, C; Murillo, $\mathrm{R}$ and Caballero, $\mathrm{P}$ (2017). Covert infection of insects by baculoviruses. Frontiers in Microbiology, 8: 1337.

Zelazny, B and Alfiler, A R (1991). Ecology of baculovirus-infected and healthy adults of Oryctes rhinoceros (Coleoptera: Scarabaeidae) on coconut palm in the Philippines. Ecological Entomology, 16: 253-259.

Zelazny, B; Lolong, A and Pattang, B (1992). Oryctes rhinoceros (Coleoptera: Scarabaeidae) populations suppressed by a baculovirus. J. Invertebrate Pathology, 59: 61-68. 